\title{
PERSEPSI MASYARAKAT TERHADAP TANAMAN HIDROPONIK DI DESA LOTTA, KECAMATAN PINELENG, KABUPATEN MINAHASA
}

\author{
Stevanus G. Kaunang \\ Melsje Y. Memah \\ Ribka M. Kumaat
}

\begin{abstract}
This study aimed to analyze and determine the public perception of hydroponic plant in the village Lotta, Pineleng Districts, views of the variables to be studied in terms of knowledge and personal characteristics and factors that, cultivation of hydroponic plants, seedlings, planting, remove seeds, caring for plants, harvesting, cleaning pipes, control water for circulation, plant nutrion, seed replacement, stimulus, personal factors, factors influence groups, cultural factors using a likert scale analysis tool. This aims was conducted over four months from February to the month of May 2016 from preparation to the arrangement of research reports. The location of research is Sentrum Agraris Lotta in the village Lotta districts Pineleng. This research uses primary data and secondary data. Primary data was obtained from 30 respondents using questionnaires, while secondary data obtained from the office Lotta village. The sampling method in this study is using purposive sampling method. The results of this study show that the public perception of plant hydroponic in the village Lotta districts Pineleng to categorize understand/agree as seen from the result obtained, that respondents will understand and know how to plant hydroponic and would like hydroponic plants.
\end{abstract}

Keywords:public perception,hydroponic plants,Lotta Village, Minahasa

\begin{abstract}
ABSTRAK
Penelitian ini bertujuan untuk menganalisis dan mengetahui persepsi masyarakat terhadap tanaman hidroponik di Desa Lotta Kecamatan Pineleng, Kabupaten Minahasa dilihat dari variabel yang akan diteliti dari segi pengetahuan dan karakteristik faktor pribadi yaitu budidaya tanaman hidroponik, bibit, penanaman, memindahkan bibit tanaman, merawat tanaman, panen, pembersihan pipa, pengontrolan air untuk sirkulasi, pemberian nutrisi tanaman, pergantian bibit, stimulus, faktor pribadi, faktor pengaruh kelompok, faktor kultural dengan menggunakan alat analisis skala likert. Penelitian ini dilaksanakan selama empat bulan yaitu dari bulan februari sampai dengan bulan mei tahun 2016, mulai dari persiapan sampai penyusunan laporan penelitian. Tempat penelitian adalah Sentrum Agraris Lotta di Desa Lotta Kecamatan Pineleng. Penelitian ini menggunakan data primer dan data sekunder. Data primer diperoleh dari 30 responden dengan menggunakan kuisioner. Sedangkan data sekunder diperoleh dari kantor Hukum Tua Desa Lotta. Metode pengambilan sampel dalam penelitian ini menggunakan metode purposive sampling. Hasil penelitian ini menunjukkan bahwa persepsi masyrakat terhadap tanaman hidroponik di Desa Lotta Kecamatan Pineleng berkategorikan mengerti/setuju karena melihat dari hasil yang di dapat, bahwa responden mengerti akan hidroponik serta mengetahui cara penanaman tanaman hidroponik dan menyukai akan tanaman hidroponik.
\end{abstract}

Kata kunci: persepsi masyarakat, tanaman hidroponik, Desa Lotta, Kabupaten Minahasa 


\section{PENDAHULUAN}

\section{Latar Belakang}

Lahan pertanian semakin sempit akibat beralihnya fungsi lahan pertanian menjadi daerah perindustrian, sehingga budidaya hidroponik dianggap tepat untuk memanfaatkan lahan yang tersedia sebaik-baiknya. Prihmantoro dan indriani (1999) dalam Sibarani (2005) mengatakan, dengan sistem hidroponik di pakai berbagai media tanam, seperti arang sekam, sekam, pasir, zeolit, rockwoll, gambut (peat mass), dan serbuk sabut kelapa. Novianti (2011) mengatakan, Ini sebuah peluang usaha yang bagus baik bagi kita sebagai calon-calon pekebun, petani dan masyarakat tanaman hidroponik. Masih banyak pasar tanaman hidroponik yang belum tergarap, masih butuh banyak pekebun-pekebun baru untuk memenuhi tanaman hidroponik ini. Hidroponik merupakan suatu metode bercocok tanam tanpa menggunakan tanah seperti metode pertumbuhan pertanian. Dengan memanfaatkan air tanpa menggunakan tanah dengan menekan pada pemenuhan kebutahan nutrisi bagi tanaman. Kebutuhan air pada hidroponik lebih memilih untuk menjual lahan-lahan yang mereka miliki untuk mendapatkan uang secara cepat. Dan begitu cepat tanah yang terjual karna harga yang masih terjangkau dan Desa Lotta merupakan tempat yang strategis karena memiliki akses jalan yang menyambungkan Kota Manado dan Kota Tomohon. Akibat dari penjualan tanah tersebut, petani yang biasanya mengolah lahan dari pemiliknya dan juga dari lahannya sendiri, harus mengganti pekerjaan petani menjadi tukang bangunan, maupun tukang ojek, wirausaha atau mencari lahan baru untuk di olahnya.

Pengalihan lahan menjadi daerah perumahan sangatlah susah bagi para petani untuk menanam, namun tanaman hidroponik mampu untuk mengatasi hal tersebut, karena tanaman hidroponik bisa di tanam di daerah rumahan karena hidroponik tidak menggunakan tanah untuk menanam, hanya membutuhkan tempat untuk alat penampungan nutrisi guna untuk memaksimalkan pertumbuhan tanaman. Namun masih kurang mengerti masyarakat, dari tanaman hidroponik sedikit dari pada kebutuhan air pada budidaya dengan tanah. Hidroponik menggunakan air yang lebih efisien, jadi cocok diterapkan pada daerah yang memiliki pasokan air yang terbatas.

Desa Lotta adalah salah satu desa pemekaran dari Desa Pineleng Kecamatan Pineleng. Desa Lotta merupakan desa yang berpotensial, karena terdapat Perusahaan Air Minum (PAM) dalam Desa Lotta yang di alirkan ke Manado, guna untuk memenuhi pasokan air untuk kebutuhan dan keperluan sehari-hari. Adanya tempat pertanian di desa Lotta yaitu Sentrum Agraris Lotta (SAL), merupakan tempat usaha petani, dan juga guna untuk tempat pelatihan pertanian. Terdapat pula Wisma Lorenzo yang merupakan tempat untuk rekoleksi, dan Taman Makam Pahlawan Makam Imam Bonjol, menjadi salah satu tempat pariwisata. Keadaan pertanian di Desa Lotta, masih banyak lahan yang belum di olah karena para petani di Desa Lotta sudah sedikit, banyak yang beralih lebih memilih pekerjaan menjadi tukang bangunan, tukang ojek, wirausaha, pegawai kantoran, pegawai sipil, polisi, TNI. Hal ini berpengaruh karena adanya peralihan lahan-lahan pertanian menjadi daerah perumahan. Para pemilik tanah ini, karena tidak semua masyarakat melihat langsung cara kerja serta keuntungan hidroponik ini. Dalam penyuluhan tentang hidroponik di Sentrum Agraris Lotta (SAL) yang di hadiri dengan tidak begitu banyak masyarakat yang datang, lebih dominan para anak muda. Dikatakan hidroponik sangatlah baik bagi kita karena menguntunggkan, baik dalam segi materi setelah di panen, maupun dalam segi kesehatan, karena hidroponik tidak menggunakan pestisida dan harga jual hidroponik lebih besar dari tanaman yang di tanaman secara konvensional.

Sentrum Agraris Lotta (SAL) terdapat dua macam usaha baik itu dalam sektor pertanian maupun peternakan. Dalam sektor peternakan terdapat usaha ternak Babi dan budi daya air tawar. Dalam sektor pertanian terdapat beberapa macam tanaman untuk ditanam dan biasanya menggunakan tiga sistem cara penanaman, baik penanaman secara sistem Organik, Non Organik, maupun dengan cara hidroponik. Dalam hal ini karakteristik yang utama yaitu hidroponik. Namun hidroponik dalam masyarakat masih kurangnya 
pengetahuan tentang tanaman hidroponik karena, kurang adanya penyuluhan tentang hidroponik sehingga antusiasme dari masyarakat untuk hidroponik masih kurang.

Masyarakat yang telah mengetahui tentang cara penanaman tanaman hidroponik tersebut, tidak mau ikut andil dalam hidroponik untuk memberikan atau membagi informasi serta keahlian berhidroponik. Hidroponik sangatlah baik karena tanaman tersebut memiliki hasil yang menguntungkan, dengan harga jual yang lebih dari tanaman biasanya, karena memiliki banyak keuntungan yaitu, bebas pestisida, meminimalisir hama dan penyakit, masa panen lebih cepat, tempat penanaman bisa di daerah perkotaan, dan juga memiliki hasil yang maksimal. Hidroponik pula bisa dikerjakan oleh siapa saja bukan cuma petani, pegawai swasta, pegawai sipil, maupun tukang bangunan juga bisa berhidroponik, karena pengurusan tanaman hidroponik ini sangatlah mudah, karena hanya menjaga kadar air, nutrisi dan pencayaan matahari apakah sudah cukup atau tidak.

Keberadaan masyarakat dalam tanaman hidroponik ini masih sangat kurang. Permasalahan yang kerap di alami masyarakat, kurang begitu andil untuk hadir dalam suatu penyuluhan untuk mengetahui tanaman hidroponik ini karena sibuk dengan pekerjaan dan juga karna kurangnya penyuluhan. Sehingga masih banyak masyarakat yang belum mengetahui tanaman hidroponik. Oleh karena itu penting untuk mengetahui persepsi masyarakat terhadap hidroponik. Penelitian ini mencoba menjawab bagaimana persepsi masyarakat terhadap tanaman hidroponik, dan untuk mendukung pengelolahan dan manfaat hidroponik itu sendiri, yang di laksanakan di Desa Lotta.

\section{Perumusan Masalah}

Berdasarkan uraian diatas maka yang menjadi rumusan masalah yaitu begaimana persepsi masyarakat terhadap tanaman hidroponik di Desa Lotta.

\section{Tujuan Penelitian}

Menganalisis dan mengetahui persepsi masyarakat terhadap tanaman hidroponik di Desa Lotta.

\section{Manfaat Penelitian}

Sebagai bahan pengetahuan mengenai persepsi masyarakat terhadap tanaman hidroponik, dan untuk membantu masyarakat mengetahui apa tanaman hidroponik itu, yang berada di Desa Lotta.

\section{METODE PENELITIAN}

\section{Waktu Penelitian Dan Tempat}

Penelitian ini berlangsung selama empat bulan sejak bulan Februari 2016 sampai Mei 2016. Tempat penelitian Di Desa Lotta.

\section{Metode Pengempulan Data}

Adapun metode pengumpulan data di ambil yaitu :

1. Data yang dikumpulkan dalam penelitian ini adalah dengan cara observasi melalui pengamatan langsung terhadap tanaman hidroponik.

2. Data primer merupakan data yang diperoleh dari hasil wawancara langsung dengan masyarakat/responden melalui kuisioner yang telah disiapkan.

3. Data sekunder, merupakan data yang diperoleh dari hukum tua di Desa Lotta.

Pengambilan data yang di ambil sebanyak 30 responden, yang ada di Desa Lotta.

\section{Konsep Dan Pengukuran Variabel}

\section{Karakteristik Anggota Masyarakat Hidroponik Di Desa Lotta.}

a. Nama yaitu dari anggota masyarakat.

b. Umur yaitu usia dari masyarakat. Di ukur dengan tahun.

c. Pendidikan yaitu yang ditetapkan berdasarkan tingkat pendidikanya mulai SD, SMP, SMA, hingga sarjana.

d. Jenis kelamin yaitu Lakilaki/Perempuan.

e. Pekerjaan yaitu pekerjaan yang di jalani oleh masyarakat. 


\section{Persepsi Dari Pengetahuan Dan Karakteristik Faktor Pribadi}

Persepsi positif di ukur dari penjumlahan antara pernyataan mengerti/setuju dan sangat mengerti/sangat setuju, dan persepsi negative di ukur dari penjumlahan antara pernyataan tidak mengerti/tidak setuju dan sangat tidak mengerti/sangat tidak setuju.
1) Budidaya tanamam hidroponik
a. Keuntungan
b. Lebih baik
c. Di berbagai musim
2) Bibit
a. Bibit dari luar
b. Bibit dari toko
c. Bibit sendiri
3) Penanaman
a. Tebar benih secara teratur
b. Mengamburkan benih
c. Penyamaian
4) Memindahkan bibit tanaman
a. Wadah gelas
b. Ke pipa
c. Busah
5) Merawat tanaman
a. Setiap hari
b. Seminggu sekali
c. Satu bulan sekali
6) Panen
a. Perorangan
b. Sewa pekerja
c. Menggunakan alat seadanya
7) Pembersihan pipa
a. Setelah pemanenan
b. Dua minggu sekali
c. Satu bulan sekali
8) Pengontrolan pompa air untuk sirkulasi
a. Secara rutin
b. Kadang-kadang
c. Tidak sama sekali
9) Pemberian nutrisi tanaman
a. Dua hari sekali
b. Dua minggu sekali
c. Satu bulan sekali
10) Pergantian Bibit
a. Setelah panen
b. Sebelum panen

\section{Pengetahuan}

Pengetahuan, sampai dimana tingkat pengetahuan masyarakat dalam menanam tanaman hidroponik di Desa Lotta.

Pengetahuan yang di ukur dalam penelitian ini merupakan pengetahuan dasar dari masyarakat tentang cara menanam tanaman hidroponik. Pengetahuan yang di ukur yaitu :

\section{c. Tidak panen}

\section{Karakteristik Faktor Pribadi}

Karakteristik dari faktor pribadi dan sosial yang dapat mempengaruhi persepsi seseorang menurut Thoha dalam Rachman (2013). Karakteristik yang di ukur yaitu :

1). Stimulus (Rangsangan)

a. Respon

b.Kesadaran

2). Faktor pribadi

a. Kemauan

b.Motivasi

3). Faktor pengaruh kelompok

a.Ikut serta

b.Bersama-sama

4) Faktor kultural
a. Persetujuan masyarakat
b. Adaptasi lingkungan

\section{Metode Pengambilan Sampel}

Pemgambilan sampel dilakukan dengan cara menggunakan metode purposive sampling pada responden masyarakat di Desa Lotta.

\section{Metode Analisis Data}

Dengan menggunakan analisis deskriptif yaitu agar bisa melihat persepsi masyarakat terhadap tanaman hidroponik dan dengan menggunakan pengukuran pengskalaan likert dengan table check list.

Setiap jawaban di hubungkan dengan bentuk pertanyaan dan dukungan yang di ungkapkan dengan kata-kata pada persepsi pengetahuan yang di kategorikan sebagai berikut :
a. Sangat mengerti
skor : 5
b. Mengerti
skor : 4
c. Ragu-ragu
skor : 3 
Pada persepsi kerakteristik faktor pribadi
a. Sangat setuju
skor : 5
b. Setuju
skor : 4
c. Ragu-ragu
skor : 3

Dengan cara perhitungan skor :

$$
\begin{aligned}
& \text { S5 }=5 \times 30=150 \\
& \text { S4 }=4 \times 30=120 \\
& \text { S3 }=3 \times 30=90
\end{aligned}
$$

Jumlah skor ideal untuk setiap pertanyaan skor tertinggi $=150$ (sangat setuju) Jumlah skor

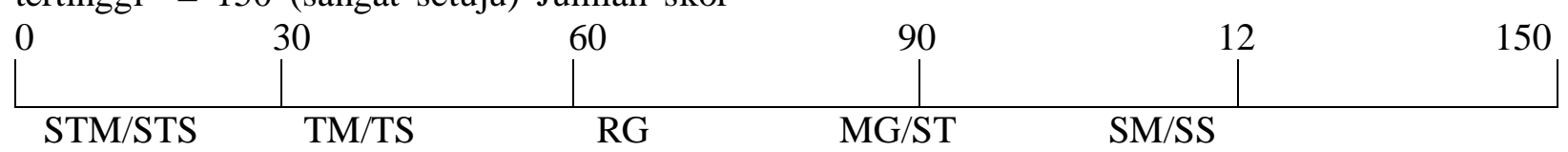

Cara perhitungan skor keseluruhan untuk mengetahui persepsi masyarakat terhadap tanaman hidroponik :

$\mathrm{S} 5=5 \times 30 \times 38=5700$

$\mathrm{S} 4=4 \times 30 \times 38=4560$

$\mathrm{S} 3=3 \times 30 \times 38=3420$

$\mathrm{S} 2=2 \times 30 \times 38=2280$

$\mathrm{S} 1=1 \times 30 \times 38=1140$

Jumlah skor ideal untuk keseluruhan pertanyaan tertinggi $=5700$ di kategorikan sebagai berikut :
d. Tidak setuju
skor : 2
e. Sangat tidak setuju
skor:1

Jumlah skor tiap kriterium = capaian skor $\mathrm{x}$ jumlah responden untuk :

$\mathrm{S} 2=2 \times 30=60$
$\mathrm{~S} 1=1 \times 30=30$

terendah $=30$ (sangat tidak setuju), dengan interpretasi nilai :

\author{
Jumlah Skor Seluruh Kriterium = Capaian \\ Jumlah Skor x Jumlah Responden x Jumlah \\ Pertanyaan Untuk : \\ Jumlah skor terendah $=1140$
}

Analisis data yang di gunakan merupakan analisis deskriptif yang di ukur dengan skala likert dimana menurut Riduwan (2008) adalah sebagai berikut:

$$
\text { Persepsi Masyarakat }=\frac{\text { Jumlah Skor Hasil Pengumpulan Data }}{\text { Jumlah Skor Ideal Tertinggi }} \times 100 \%
$$

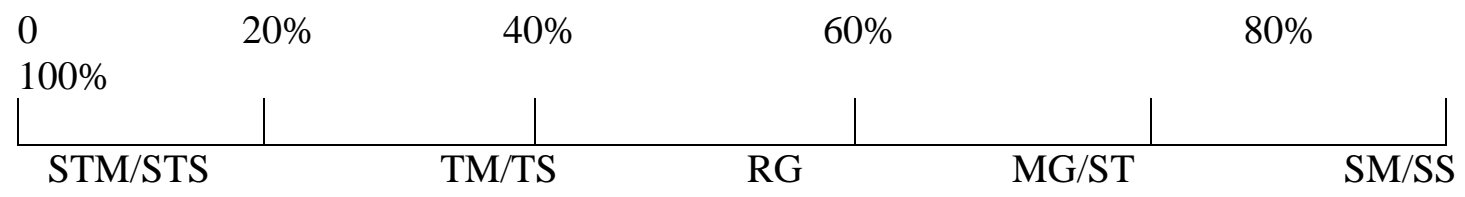

Keterangan Kriteria inerpretasi Skor :

Angka $0 \%-20 \%=$ Sangat tidak mengerti /Sangat tidak setuju

Angka $21 \%-40 \%=$ Tidak mengerti/Tidak setuju

Angka 41\% - 60\% = Ragu-ragu

Angka $61 \%-80 \%=$ Mengerti/Setuju

Angka $81 \%-100 \%=$ Sangat mengerti/Sangat setuju

\section{HASIL DAN PEMBAHASAN}

\section{Sejarah}

\section{Profil Desa}

Desa lotta Kecamatan Pineleng Kabupaten Minahasa, berdiri pada tanggal 8
Maret 2012 adalah hasil pemekaran dari Desa Pineleng Dua dengan pejabat Hukum Tua / Kepala Desa yang pertama adalah Bapak Daniel S.Wongkar. Asal usul penduduk pribuminya adalah To'u Pa'Kinilowen (Orang Kinolow) dengan nama kampung Wanua Ure Kalih (Kampung Tua Kalih) wilayah Distrik Kakaskasen. Wanua Kalih kemudian lebih di kenal dengan sebutan lotta. Pada tahun 1905 Lotta mengalami wabah penyakit yang kala itu belum ada obat untuk menyembuhkan penyakit tersebut, dan di duga penyakit yang dialami yaitu penyakit kolera, sehingga banyak korban meninggal pada waktu itu, maka masyarakat mengungsi ke beberapa desa tetangga yaitu Desa Kali, 
Warembungan,Tinoor, Koka dan Pineleng yang artinya dipilih karena penduduk Lotta memilih tempat tinggal yang baru yaitu Desa Pineleng dimana didalamnya termasuk Desa Pineleng dua. Kemudian suku, bahasa dan budaya aslinya yakni TOMBULU tetapi lewat perkembangan pemukiman dan populasi penduduk dari tahun ke tahun sampai pada pemekaran di tahun 1985 dari desa pineleng maka penduduk Desa Pineleng Dua telah beragam suku, agama dan budaya, ini disebabkan karena Pineleng pada umumnya berbatasan langsung dengan Kota Manado Ibu Kota Provinsi Sulawesi Utara yang percepatan pembangunan Kota Manado lebih memilih pindah ke Lotta yang memang masih luas arealnya serta jauh dari kebisingan Kota dan udara yang masih sejuk.

Kemudian dengan melihat perkembangan penduduk cukup pesat serta keperluan pelayanan administrasi yang dirasakan masyarakat jaraknya cukup jauh untuk ke kantor Desa, maka atas keinginan bersama serta tokoh-tokoh masyarakat dengan Pemerintah Desa Pineleng Dua berhasil di mekarkan Lotta menjadi satu Desa dengan nama Desa Lotta. Latar belakang penduduknya terdiri dari berbagai suku, agama, dan budaya di berbagai daerah di Indonesia. Namun walaupun kondisi masyarakatnya yang sangat heterogen beragam budaya dan latar belakang suku, ras dan golongan agama yang berbeda, tetapi keberagaman inilah menjadi modal bagi masyarakat untuk saling menghormati satu dengan yang lainnya dengan semboyan "Torang Samua Basudara" yang artinya kita semua Bersaudara tetap terjalin dengan baik dan juga Budaya Mapalus masih terus di lestarikan sehingga keamanan dan kenyamanan selalu dirasakan oleh masyarakat.

\section{Demografi}

\section{Letak Wilayah Dan Luas Wilayah}

Desa Lotta adalah sebuah Desa yang terletak di Wilayah Kecamatan Pineleng Kabupaten Minahasa, Propinsi Sulawesi Utara. Terdiri dari 4 Jaga/Dusun dengan batas wilayah :

Sebelah Utara : Desa Pineleng Satu Timur
Sebelah Timur : Desa Pineleng Satu Timur dan Kali

Sebelah Selatan : Desa Tinoor Dua

Sebelah Barat : : Desa Pineleng Dua

Desa Lotta memanjang dari utara ke selatan dengan luas 185 Ha,beriklim tropis dan berada pada ketinggian \pm 150 meter diatas permukaan laut.

\section{Kependudukan}

$\begin{array}{ll}\text { a. Jumlah Penduduk } & : 1385 \text { Jiwa } \\ \text { Laki-laki } & : 720 \text { Jiwa } \\ \text { Perempuan } & : 665 \text { Jiwa } \\ \text { b. Jumlah Kepala Keluarga } & : 332 \mathrm{KK}\end{array}$

\section{Karakteristik Responden}

\section{Umur Responden}

Untuk mengetahui klasifikasi umur responden di Desa Lotta Kecamatan Pineleng dapat dilihat pada Tabel 1.

\section{Tabel 1. Klasifikasi Responden Menurut Kelompok Umur}

\begin{tabular}{cccc} 
No & $\begin{array}{c}\text { Kelompok } \\
\text { Umur }\end{array}$ & Jumlah & $\begin{array}{c}\text { Persentase } \\
(\%)\end{array}$ \\
\hline 1 & $<21$ & 18 & $60 \%$ \\
2 & $21-25$ & 9 & $30 \%$ \\
3 & $>25$ & 3 & $10 \%$ \\
\hline & Jumlah & 30 & $100 \%$ \\
\hline
\end{tabular}

Sumber : Data Hasil Olahan 2016

Pada Tabel 1 dapat dilihat bahwa presentase tingkat umur yang tertinggi dari responden yang tinggal di Desa Lotta Kecamatan Pineleng adalah klasifikasi responden yang berumur kurang dari 21 tahun dengan jumlah 18 orang dengan presentase $60 \%$ dan responden yang berumur 21-25 tahun berjumlah 9 orang dengan presentase $30 \%$ dan yang terendah adalah klasifikasi 
responden yang lebih dari 25 tahun dengan jumlah 3 orang dengan presentasi $10 \%$.

\section{Pendidikan Responden}

Untuk mengetahui klasifikasi responden berdasarkan pendidikan, dapat dilihat pada Tabel 2.

Tabel 2. Klasifikasi Responden Berdasarkan Tingkat Pendidikan

\begin{tabular}{cccc}
\hline No & Pendidikan & $\begin{array}{c}\text { Jumlah } \\
\text { (Orang) }\end{array}$ & $\begin{array}{c}\text { Presentase } \\
(\%)\end{array}$ \\
\hline 1 & SMP & 5 & $16.66 \%$ \\
2 & SMA/SMK & 23 & $76.67 \%$ \\
3 & Perguruan Tinggi & 2 & $6.67 \%$ \\
\hline & Jumlah & 30 & $100 \%$ \\
\hline
\end{tabular}

Sumber : Data Hasil Olahan 2016

Pada table 2. Dapat dilihat bahwa sebagian besar responden memiliki tingkat pendidikan SMA/SMK dengan jumlah 23 orang dengan presentase $76.67 \%$ dan tingat pendidikan SMP dengan jumlah 5 orang dengan presentase $16.66 \%$. Dan yang terendah tingkat pendidikan responden perguruan tinggi dengan jumlah 2 orang dengan presentase $6.67 \%$.

\section{Jenis Kelamin}

Untuk mengetahui klasifikasi responden berdasarkan jenis kelamin dapat dilihat pada tabel 3.

Tabel 3. Klasifikasi Responden Berdasarkan Jenis Kelamin.

\begin{tabular}{cccc}
\hline No & $\begin{array}{c}\text { Jenis } \\
\text { Kelamin }\end{array}$ & $\begin{array}{c}\text { Jumlah } \\
\text { (Orang) }\end{array}$ & $\begin{array}{c}\text { Presentase } \\
(\%)\end{array}$ \\
\hline 1 & Laki-laki & 27 & $90 \%$ \\
2 & Perempuan & 3 & $10 \%$ \\
\hline & Jumlah & 30 & $100 \%$ \\
\hline
\end{tabular}

Sumber : Data Hasil Olahan 2016

Pada Tabel 3. Terlihat bahwa jumlah responden berdasarkan jenis kelamin sebagian besar adalah Laki-laki berjumlah 27 orang dengan presentase $90 \%$. Sedangkan perempuan berjumlah 3 orang dengan presentase $10 \%$.

\section{Pekerjaan}

Dari Tabel 4 dapat dilihat bahwa mahasiswa/pelajar lebih mendominasi yaitu sebanyak 14 orang dengan persentase $46.67 \%$, tukang sebanyak 3 orang dengan presentase $10 \%$, swasta sebanyak 11 orang dengan persentase $36.67 \%$, dan wiraswasta sebanyak 2 orang dengan persentase $6.66 \%$.

Tabel 4. Klasifikasi Responden Berdasarkan Pekerjaan

\begin{tabular}{cccc}
\hline No & Pekerjaan & $\begin{array}{c}\text { Jumlah } \\
\text { (Orang) }\end{array}$ & $\begin{array}{c}\text { Persentase } \\
(\%)\end{array}$ \\
\hline 1 & Pelajar/Mahasiswa & 14 & $46.67 \%$ \\
2 & Tukang & 3 & $10 \%$ \\
3 & Swasta & 11 & $36.67 \%$ \\
4 & Wiraswasta & 2 & $6.66 \%$ \\
\hline & Jumlah & 30 & $100 \%$ \\
\hline
\end{tabular}

Sumber : Data Hasil Olahan 2016

\section{Persepsi Masyarakat}

\section{Persepsi Dari Pengetahuan}

Persepsi mayarakat terhadap tanaman hidroponik dari segi pengetahuan dalam menanam tanaman hidroponik dapat di jelaskan dari sub variabel yang telah disediakan sebagai berikut :

\section{Budidaya Tanaman Hidroponik}

Untuk melihat persepsi masyarakat di Desa Lotta Kecamatan Pineleng, mengenai persepsi masyarakat terhadap tanaman hidroponik dengan Sub Variabel Keuntungan dapat di lihat pada tabel 5 (Tabel dilampirkan).

Dari tabel 5. Dapat di lihat bahwa total skor untuk sub variabel Budidaya tanaman hidroponik di peroleh 282 skor dengan kategori Mengerti. Hal ini menurut responden sebagian banyak mengetahui cara budidaya tanaman hidroponik dan juga sebagian tidak mengetahui. Diantara ketiga indikator di peroleh nilai skor yang tinggi yaitu 120 dengan persentase $80 \%$ pada indikator keuntungan dengan kategori Sangat mengerti. Tingginya skor tersebut di sebabkan karena masyarakat mengetahui akan keuntungan dari 
tanaman hidroponik untuk bididaya terhadap tanaman hidroponik. Pada indikator lebih baik terdapat 22 skor dengan persentase $36.67 \%$ pada kategori Tidak mengert ini di sebabkan karena masyarakat mengerti tidak bahwa tanaman hidrooponik lebih unggul dari tanaman yang di tanaman secara konvensional, dan untuk indikator di berbagai musim yaitu 28 skor dengan persentase 46,67 $\%$ pada kategori Tidak mengerti, tingginya skor tersebut karena masyarakat tidak mengetahui bahwa tanaman hidroponik tentunya bisa di tanam di berbagai musim.

Untuk mendapatkan gambaran yang jelas mengenai persepsi masyarakat terhadap tanaman hidroponik dapat di lihat pada gambar 1 dengan interpretasi nilai.

\begin{tabular}{lccc|c|c|}
\multicolumn{1}{c}{} & \multicolumn{1}{c}{ STM } & \multicolumn{2}{c}{ TM } & \\
\multicolumn{1}{c}{ RG } & \multicolumn{2}{c}{ MG } & SM \\
\hline 0 & & 90 & 180 & & 270 \\
282 & & 360 & 450 &
\end{tabular}

Gambar 1. Skala Persepsi Masyarakat Terhadap Tanaman Hidroponik Dengan Sub Variabel Budidaya Tanaman Hidroponik.

Keterangan $\quad: S M=$ Sangat Mengerti

MG $=$ Mengerti

$\mathrm{RG}=$ Ragu-ragu

$\mathrm{TM}=$ Tidak Mengerti

STM = Sangat Tidak

Mengerti

Dari Gambar 1. Dapat di jelaskan bahwa total skor 282, untuk persepsi masyarakat terhadap tanaman hidroponik skor $(270$ - 360) dengan kategori mengerti. Hal ini menurut jawaban responden bahwa sebagian besar mengetahui cara budidaya tanaman hidroponik, dan sebagian lagi kurang mengerti.

\section{Bibit}

Untuk melihat persepsi masyarakat di Desa Lotta Kecamatan Pineleng. Mengenai persepsi masyarakat terhadap tanaman hidroponik dengan sub variabel bibit dapat di lihat pada tabel 6 (Tabel dilampirkan).

Dari tabel 6 dapat dijelaskan bahwa total skor yang diperoleh yaitu 322 skor dengan kategori mengerti. Hal ini berarti bahwa menurut jawaban responden sebagian besar lebih tahu bagaimana pengambilan bibit yang tepat. Diantara ketiga indikator di peroleh nilai skor yang sangat tinggi yaitu 76 skor dengan persentase $63.34 \%$ pada indikator bibit di ambil dari luar dengan kategori mengerti. Hal ini disebabkan karena kebanyakan bibit yang berkualitas unggul lebih banyak dari luar. Sedangkan indikator bibit di beli dari toko yaitu 64 skor dengan persentase $53.33 \%$ pada kategori mengerti. Tinggi kategori tersebut di sebabkan karena pembelian bibit dari toko sangatlah mudah dan cepat. Sedangkan indikator bibit di buat sendiri yaitu 28 skor dangan persentase 46.67 $\%$ kategori tidak mengerti. Tingginya skor tersebut karena sukarnya pembuatan bibit sendiri, kecuali pengambilan hasil buah yang telah di tanam kemudian di jadikan bibit.

Untuk gambaran lebih jelas mengenai persepsi masyarakat terhadap tanaman hidroponik dengan sub variabel bibit dapat dilihat pada gambar 2 dengan interpretasi nilai

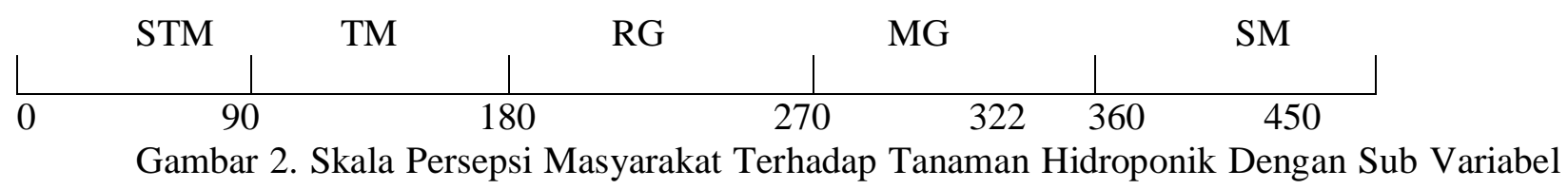

Bibit.

$\begin{array}{ll}\text { Keterangan } & : \text { SM }=\text { Sangat Mengerti } \\ \text { MG }=\text { Mengerti } \\ \text { RG }=\text { Ragu-ragu } \\ \text { TM }=\text { Tidak Mengerti } \\ \text { STM }=\text { Sangat Tidak Mengerti }\end{array}$


Dari Gambar 2. Dapat di jelaskan bahwa total skor 322, untuk persepsi masyarakat terhadap tanaman hidroponik skor (270 - 360) dengan kategori mengerti. Hal ini menurut jawaban responden bahwa paling banyak masyarakat mengetahui cara pembelian bibit yang bagus dan berkualitas untuk tanaman hidroponik.

\section{Penanaman}

Untuk melihat persepsi masyarakat di Desa Lotta Kecamatan Pineleng. Mengenai persepsi masyarakat terhadap tanaman hidroponik dengan sub variabel penanaman dapat di lihat pada tabel 7 (Tabel dilampirkan).

Dari tabel 7 dapat dijelaskan bahwa total skor yang diperoleh yaitu 375 skor dengan kategori mengerti. Hal ini berarti bahwa menurut jawaban responden masyarakat lebih besar mengetahui cara penanaman benih. Diantara ketiga indikator di peroleh nilai skor yang sangat tinggi yaitu 95 skor dengan persentase $63.33 \%$ pada indikator tebar benih secara teratur dengan kategori sangat mengerti. Hal ini disebabkan karena masyarakat begitu mengerti tentang cara tebar benih. Sedangkan indikator mengamburkan benih yaitu 64 skor dengan persentase $53.33 \%$ pada kategori mengerti. Tinggi kategori tersebut di sebabkan karena cara pengamburan benih merupakan proses penanaman bibit yang dilakukan secara tidak teratur namun proses pertumbuhannya akan tetap sama dengan cara tabur benih secara teratur. Sedangkan indikator penyamaian yaitu 55 skor dangan persentase $36.67 \%$ kategori sangat mengerti. Tingginya skor tersebut karena pentingnya penyamaian pada proses pertumbuhan untuk tanaman hidroponik dan para responden memahami cara penyamaian tersebut.

Untuk gambaran lebih jelas mengenai persepsi masyarakat terhadap tanaman hidroponik dengan sub variabel penanaman dapat dilihat pada gambar 3 dengan interpretasi nilai.

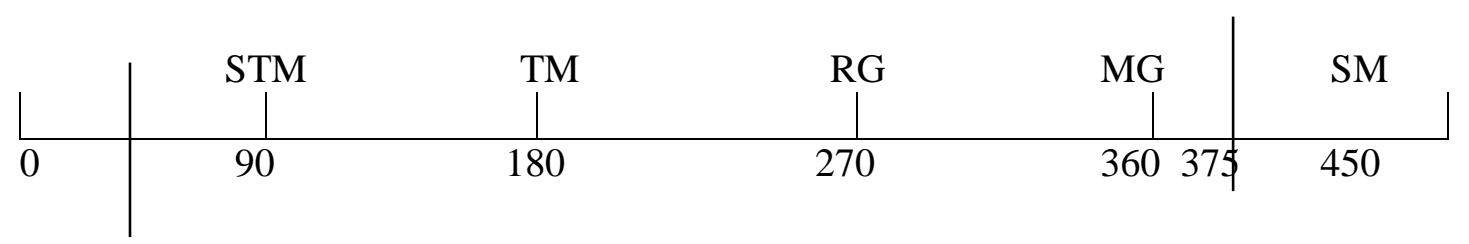

Gambar 3. Skala Persepsi Masyarakat Terhadap Tanaman Hidroponik Dengan Sub Variabel Penanaman.

$\begin{array}{ll}\text { Keterangan } & : S M=\text { Sangat Mengerti } \\ & M G=\text { Mengerti } \\ \text { RG }=\text { Ragu-ragu } \\ \text { TM }=\text { Tidak Mengerti } \\ \text { STM }=\text { Sangat Tidak }\end{array}$

Mengerti

Dari Gambar 3. Dapat di jelaskan bahwa total skor 375, untuk persepsi masyarakat terhadap tanaman hidroponik skor (360 - 450) dengan kategori mengerti. Hal ini menurut jawaban responden bahwa paling banyak masyarakat mengetahui bagaimana penanaman baik secara teber benih secara teratur, mengamburkan benih, dan penyamaian tanaman hidroponik.

\section{Memindahkan Bibit Tanaman}

Untuk melihat persepsi masyarakat di Desa Lotta Kecamatan Pineleng. Mengenai persepsi masyarakat terhadap tanaman hidroponik dengan sub variabel memindahkan bibit tanaman dapat di lihat pada tabel 8 (Tabel dilampirkan).

Dari tabel 8 dapat dijelaskan bahwa total skor yang diperoleh yaitu 345 skor dengan kategori mengerti. Hal ini berarti bahwa menurut jawaban responden masyarakat lebih besar mengetahui cara memindahkan bibit tanaman. Diantara ketiga indikator di peroleh nilai skor yang sangat tinggi yaitu 90 skor dengan persentase $60 \%$ pada indikator memerlukan wadah gelas untuk memindahkan bibit tanaman dengan kategori sangat mengerti. Hal ini disebabkan karena wadah gelas merupakan salah satu bagian penting dalam tanaman hidroponik karena setiap habis penyamaian tanaman akan di pindahkan pada wadah gelas. Sedangkan indikator menuju ke pipa untuk memindahkan bibit tanaman yaitu 25 skor dengan persentase $16.67 \%$ pada kategori sangat mengerti. Tinggi kategori tersebut di sebabkan karena langsung menuju ke pipa untuk memindahkan bibit tanaman merupakan preses penanaman secara 
hidroponik dimana proses pertumbuhan tanaman sampai bisa di panen di lakukan di pipa tersebut. Indikator menggunakan busah untuk memindahkan bibit tanaman yaitu 64 skor dangan persentase $53.34 \%$ kategori mengerti. Tingginya skor tersebut karena merupakan salah satu cara untuk memindahkan tanaman dengan menggunakan busah tersebut.

Untuk gambaran lebih jelas mengenai persepsi masyarakat terhadap tanaman hidroponik dengan sub variabel memindahkan bibit tanaman dapat dilihat pada gambar 4 dengan interpretasi nilai.

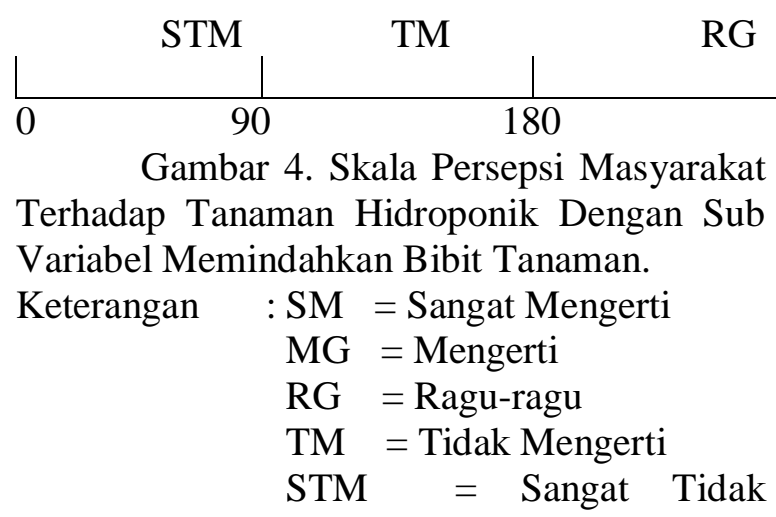

Mengerti

Dari Gambar 4. Dapat di jelaskan bahwa total skor 375, untuk persepsi masyarakat terhadap tanaman hidroponik skor (270 - 360) dengan kategori mengerti. Hal ini menurut jawaban responden bahwa paling banyak mengerti proses pemindahan bibit tanaman baik secara dengan menggunakan wadah gelas, langsung menuju ke pipa,dan juga dengan menggunakan busah untuk memindahkan bibit tanaman.

\section{Merawat Tanaman}

Untuk melihat persepsi masyarakat di Desa Lotta Kecamatan Pineleng. Mengenai persepsi masyarakat terhadap tanaman hidroponik dengan sub variabel merawat tanaman dapat di lihat pada tabel 9 (Tabel dilampirkan)

Dari tabel 9 dapat dijelaskan bahwa total skor yang diperoleh yaitu 261 skor dengan kategori ragu-ragu. Hal ini berarti bahwa menurut jawaban responden

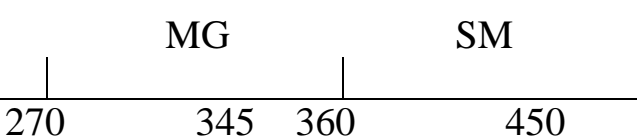

masyarakat masih belum memahami merawat tanaman. Diantara ketiga indikator di peroleh nilai skor yang sangat tinggi yaitu 125 skor dengan persentase $83.33 \%$ pada indikator merawat tanaman hidroponik setiap hari kategori sangat mengerti. Hal ini disebabkan karena agar supaya tanaman hidroponik bisa menghasilkan hasil yang maksimal. Indikator merawat tanaman hidroponik seminggu sekali yaitu 28 skor dengan persentase $46.66 \%$ pada kategori tidak mengerti. Tinggi kategori di sebabkan karena perawatan seminggu sekali tentunya daya tumbuh

tanaman tidak akan terkontrol karena jarak perawatan tanaman yang tidak sesuai. Indikator merawat tanamn hidroponik satu bulan sekali yaitu 22 skor dangan persentase $36.67 \%$ kategori tidak mengerti. Tingginya skor tersebut karena jarak perawatan tanaman yang tidak begitu efisien bagi tanaman tersebut, dengan jarak merawat tanaman yang begitu jauh, akan menyebabkan tanaman tersebut akan mengalami berbagai masalah tanaman, mulai dari tanaman akan layu, terserang hama dan penyakit.

Untuk gambaran lebih jelas mengenai persepsi masyarakat terhadap tanaman hidroponik dengan sub variabel merawat tanaman dapat dilihat pada gambar 5 dengan interpretasi nilai.

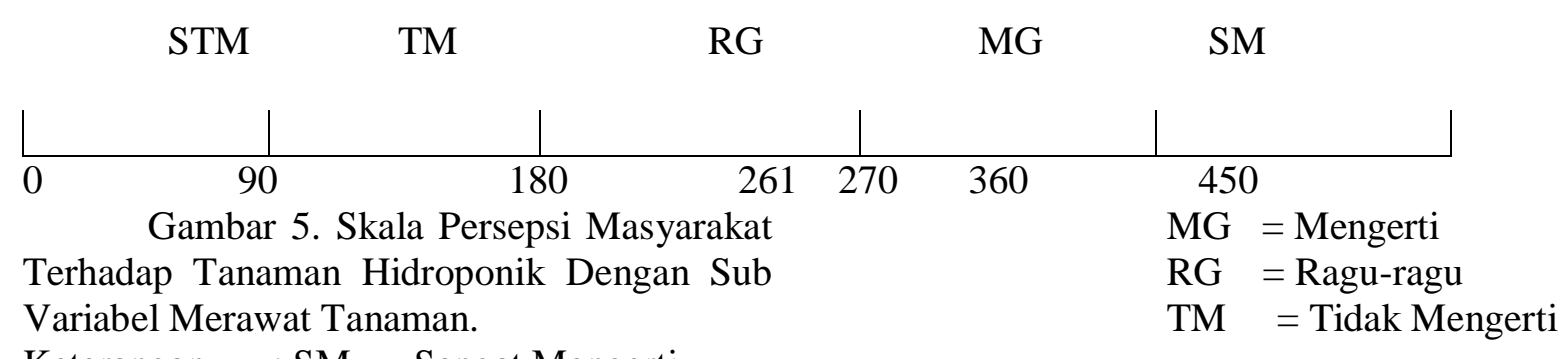




\section{Mengerti}

$$
\text { STM }=\text { Sangat Tidak }
$$

Dari Gambar 5. Dapat di jelaskan bahwa total skor 261, untuk persepsi masyarakat terhadap tanaman hidroponik skor (180 - 270) dengan kategori ragu-ragu. Hal ini menurut jawaban responden bahwa masih kurangnya pengetahuan responden masyarakat terhadap merawat tanaman sehingga kategori yang di dapat ragu-ragu.

\section{Panen}

Untuk melihat persepsi masyarakat di Desa Lotta Kecamatan Pineleng. Mengenai persepsi masyarakat terhadap tanaman hidroponik dengan sub variabel panen dapat di lihat pada tabel 10 (Tabel dilampirkan).

Dari tabel 10 dapat dijelaskan bahwa total skor yang diperoleh yaitu 339 skor dengan kategori mengerti. Hal ini berarti bahwa menurut jawaban responden masyarakat mengerti bahwa pemanenan bisa dilakukan perorangan ataupun menyewa pekerja. Diantara ketiga indikator di peroleh nilai skor yang sangat tinggi yaitu 84 skor dengan persentase $70 \%$ pada indikator pemanenan di lakukan perorangan kategori

\section{STM}

TM

RG

MG

SM

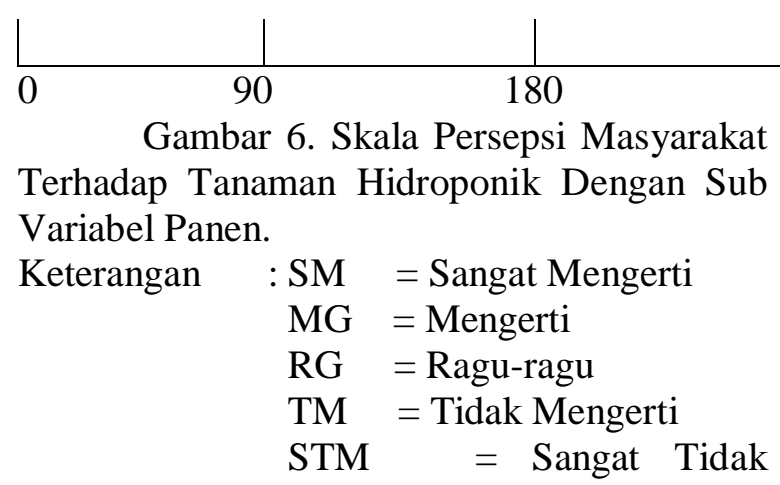

Mengerti

Dari Gambar 6. Dapat di jelaskan bahwa total skor 339, untuk persepsi masyarakat terhadap tanaman hidroponik skor (270 - 360) dengan kategori mengerti. Hal ini menurut jawaban responden masyarakat bahwa lebih banyak mengerti pemanenan untuk tanaman hidroponik.

\section{Pembersihan Pipa}

Untuk melihat persepsi masyarakat di Desa Lotta Kecamatan Pineleng. Mengenai persepsi masyarakat terhadap tanaman mengerti. Hal ini disebabkan karena tanaman hidroponik sangat mudah untuk di panen jadi bisa dilakukan perorangan saat pemanenan dalam luas lahan yang kecil. Sedangkan indikator pemanenan di lakukan oleh menyewa pekerja yaitu 56 skor dengan persentase $46.67 \%$ pada kategori mengerti. Tinggi kategori di sebabkan karena jika luas lahan tanaman hidroponik memiliki skala yang besar tentunya bisa menyewa pekerja untuk kegiatan pemanenan tanaman hidroponik. Sedangkan indikator merawat tanamn hidroponik satu bulan sekali yaitu 68 skor dangan persentase $56.66 \%$ kategori mengerti. Tingginya skor tersebut karena dalam melakukan pemanenan tanaman hidroponik tidak perlu memakai alat-alat yang khusus cukup dengan alat seadanya dalam melakukan pemanenan.

Untuk gambaran lebih jelas mengenai persepsi masyarakat terhadap tanaman hidroponik dengan sub variabel panen dapat dilihat pada gambar 6 dengan interpretasi nilai. $\begin{array}{ccc}270 & 339360 & 450 \\ & \text { hidroponik dengan sub variabel pe }\end{array}$ pipa dapat di lihat pada tabel 11 (Tabel dilampirkan).

Dari tabel 11 dapat dijelaskan bahwa total skor yang diperoleh yaitu 283 skor dengan kategori ragu-ragu. Hal ini berarti bahwa menurut jawaban responden masyarakat masih belum tahu atau ragu-ragu dalam pembersihan pipa untuk tanaman hidroponik. Diantara ketiga indikator di peroleh nilai skor yang sangat tinggi yaitu 105 skor dengan persentase $70 \%$ pada indikator pembersihan pipa di lakukan setelah pemanenen di kategori sangat mengerti. Hal ini disebabkan karena sehabis pemanenan pipa harus segera di bersihkan agar supaya pipapipa tersebut bisa langsung di pakai kembali untuk di isi tanaman. Indikator pembersihan pipa di lakukan dua minggu sekali yaitu 30 skor dengan persentase $33.34 \%$ pada kategori ragu-ragu. Tinggi kategori di sebabkan karena 
jika pembersihan pipa di lakukan dua minggu sekali setelah pemanenan maka akan sulit untuk membersihkan pipa-pipa tersebut karena jamur-jamur atau kotoran-kotoran yang ada dalam pipa sulit untuk di bersihkan. Sedangkan indikator pembersihan pipa di lakukan satu bulan sekali yaitu 24 skor dangan persentase $40 \%$ kategori tidak mengerti. Tingginya skor tersebut karena jika di lakukan

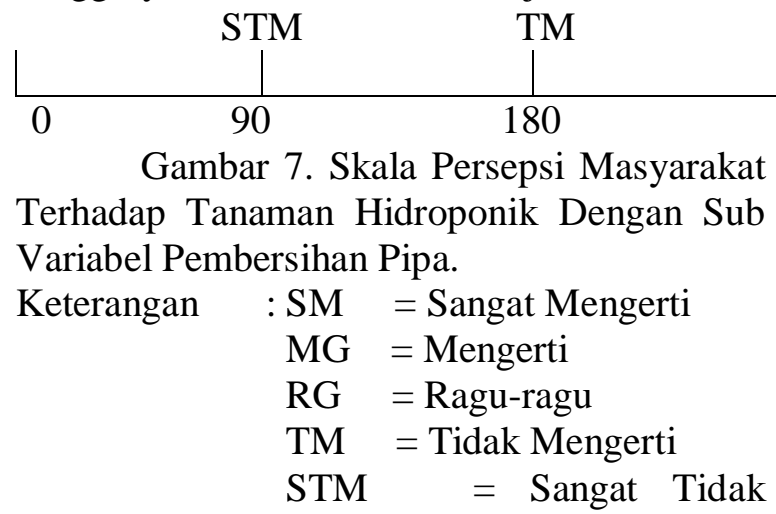

Mengerti

Dari Gambar 7. Dapat di jelaskan bahwa total skor 283, untuk persepsi masyarakat terhadap tanaman hidroponik skor (270 - 360) dengan kategori ragu-ragu. Hal ini menurut jawaban responden masyarakat bahwa sebagian telah mengerti cara pembersihan pipa berapa lama, dan sebagian lagi belum begitu mengerti karena kategori yang di dapatkan ragu-ragu.

\section{Pengontrolan Pompa Air Untuk Sirkulasi}

Untuk melihat persepsi masyarakat di Desa Lotta Kecamatan Pineleng. Mengenai persepsi masyarakat terhadap tanaman hidroponik dengan sub variabel pengontrolan pompa air untuk sirkulasi dapat di lihat pada tabel 12 (Tabel dilampirkan).

Dari tabel 12 dapat dijelaskan bahwa total skor yang diperoleh yaitu 278 skor dengan kategori ragu-ragu. Hal ini berarti bahwa menurut jawaban responden masyarakat masih belum tahu sepenuhnya pengontrolan pompa air untuk sirkulasi. pembersihan pipa satu bulan sekali tentunya akan merugikan petani hidroponik karena rugi waktu karena terlalu lama jenjang waktu dalam pembersihan pipa tersebut.

Untuk gambaran lebih jelas mengenai persepsi masyarakat terhadap tanaman hidroponik dengan sub variabel pembersihan pipa dapat dilihat pada gambar 7 dengan interpretasi nilai.

$\begin{array}{ccc}\begin{array}{c}\text { RG } \\ \mid\end{array} & \text { MG } & \text { SM } \\ 270283 & 360 & 450\end{array}$

Diantara ketiga indikator di peroleh nilai skor yang sangat tinggi yaitu 115 skor dengan persentase $76.67 \%$ pada indikator mengontrol secara rutin pompa air untuk sirkulasi di kategori sangat mengerti. Hal ini disebabkan karena pengontrolan pompa sangat penting untuk tanaman karna fungsi dari pompa guna untuk mengaliri air ke semua tanaman hidroponik lewat pipa-pipa yang ada.. Sedangkan indikator pengontrolan pompa air untuk sirkulasi di lakukan kadang-

kadang yaitu 36 skor dengan persentase $40 \%$ pada kategori ragu-ragu. Tinggi kategori di sebabkan karena jika pengontrolan di lakukan secaara tak menentu atau kadang-kadang maka penurunan debit air otomatis tidak akan terkontrol juga, jika air mulai menipis maka pertumbuhan tanaman tidak akan memiliki hasil yang maksimal. Sedangkan indikator pengontrolan pompa air untuk sirkulasi tidak perlu di lakukan yaitu 20 skor dangan persentase $33.33 \%$ kategori tidak mengerti. Tingginya skor tersebut karena jika tidak adanya pengontrolan terhadap pompa air maka air untuk di aliri ke tanaman akan habis akibatnya tanaman bisa mati.

Untuk gambaran lebih jelas mengenai persepsi masyarakat terhadap tanaman hidroponik dengan sub variabel pengontrolan pompa air untuk sirkulasi dapat dilihat pada gambar 8 dengan interpretasi nilai.

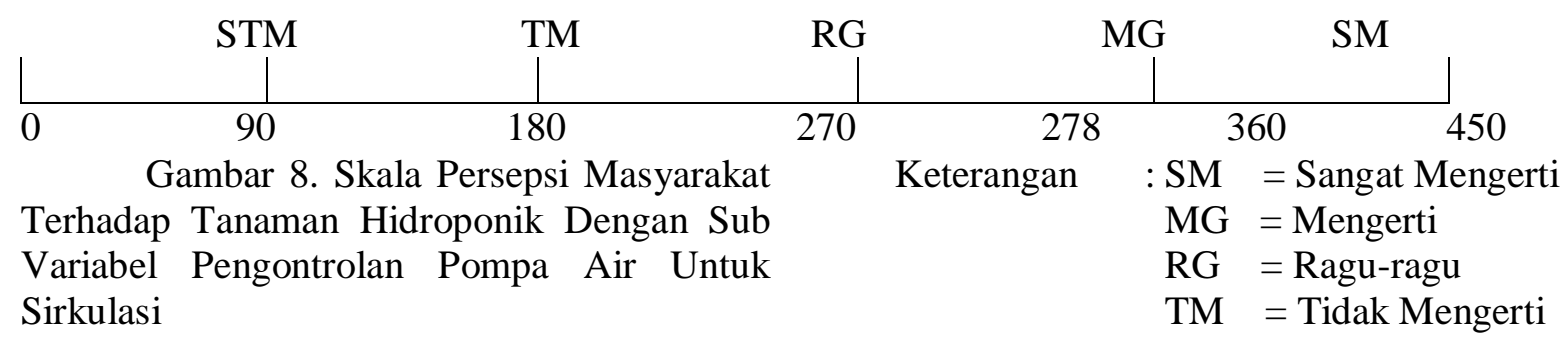




\section{Mengerti}

$$
\text { STM }=\text { Sangat Tidak }
$$

Dari Gambar 8. Dapat di jelaskan bahwa total skor 278, untuk persepsi masyarakat terhadap tanaman hidroponik skor (270 - 360) dengan kategori ragu-ragu. Hal ini menurut jawaban responden masyarakat bahwa pengontrolan pompa air itu begitu penting, namun hanya sebagian yang mengetahui pengontrolan pompa air dan sebagian lagi masih belum mengerti.

\section{Pemberian Nutrisi Tanaman}

Untuk melihat persepsi masyarakat di Desa Lotta Kecamatan Pineleng. Mengenai persepsi masyarakat terhadap tanaman hidroponik dengan sub variabel pemberian nutrisi tanaman dapat di lihat pada tabel 13 (Tabel dilampirkan).

Dari tabel 13 dapat dijelaskan bahwa total skor yang diperoleh yaitu 285 skor dengan kategori ragu-ragu. Hal ini berarti bahwa menurut jawaban responden masyarakat bahwa sebagian telah mengetahui rutinitas pemberian nutrisi tanaman. Diantara ketiga indikator di peroleh nilai skor yang sangat tinggi yaitu 95 skor dengan persentase

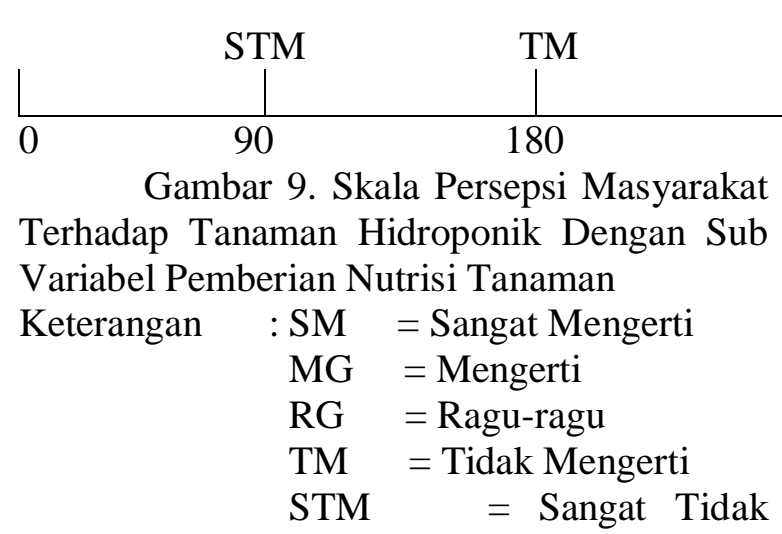

Mengerti

Dari Gambar 9. Dapat di jelaskan bahwa total skor 285, untuk persepsi masyarakat terhadap tanaman hidroponik skor (270 - 360) dengan kategori ragu-ragu. Hal ini menurut jawaban responden masyarakat masih kurangnya ketidak tahuan masyarakat dalam pemberian nutrisi tanaman, namun sebagian juga mengetahui cara pemberian nutrisi pada tanaman.

\section{Pergantian Bibit}

Untuk melihat persepsi masyarakat di Desa Lotta Kecamatan Pineleng. Mengenai
63.33\% pada indikator pemberian nutrisi dua hari sekali di kategori sangat mengerti. Hal ini disebabkan karena pemberian nutrisi tanaman sangatlah penting dan harus tepat waktu karena nutrisi tanman sangatlah berdampak besar pada tumbuh kembangnya tanaman sehingga bisa mengahasilkan tanaman hidroponik dengan maksimal. Indikator pemberian nutrisi tanaman dua minggu sekali yaitu 48 skor dengan persentase $40 \%$ pada kategori mengerti. Tinggi kategori di sebabkan karena jika pemberian nutrisi selama dua minggu sekali akan menyebabkan keterlambatan pertumbuhan pada tanaman. Indikator pemberian nutrisi satu bulan sekali yaitu 18 skor dangan persentase $30 \%$ kategori tidak mengeri. Tingginya skor tersebut karena keterlambatan pemberian nutrisi selama satu bulan maka akan menimbulkan dampak dari ketidak seimbagan tanaman yang akan bertumbuh hasil yang tidak maksimal sampai pada kematian tanaman itu sendiri.

Untuk gambaran lebih jelas mengenai persepsi masyarakat terhadap tanaman hidroponik dengan sub variabel pemberian nutrisi tanaman dapat dilihat pada gambar 9 dengan interpretasi nilai.

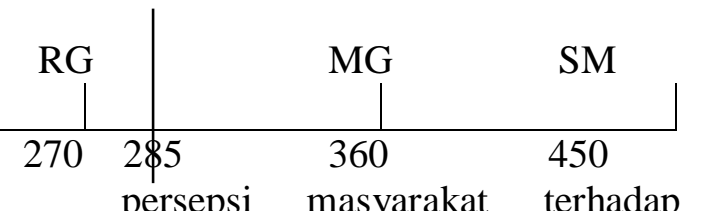

persepsi masyarakat terhadap tanaman hidroponik dengan sub variabel pergantian bibit dapat di lihat pada tabel 14 (Tabel dilampirkan)

Dari tabel 14 dapat dijelaskan bahwa total skor yang diperoleh yaitu 270 skor dengan kategori ragu-ragu. Hal ini berarti bahwa menurut jawaban responden masyarakat bahwa masih ada ketidaktahuan msyarakat dalam pergantian bibit. Diantara ketiga indikator di peroleh nilai skor yang sangat tinggi yaitu 110 skor dengan persentase $73.33 \%$ pada indikator pergantian bibit tanaman setelah panen di kategori sangat mengerti. Hal ini disebabkan karena responden mengerti pergantian bibit tanaman setelah panen itu penting agar proses pemanenan akan terus menerus ada dan juga supaya masa panen tidak memiliki jenjang waktu yang lama. Indikator pergantian bibit tanaman sebelum panen yaitu 40 skor dengan 
persentase $66.66 \%$ pada kategori tidak mengerti. Tinggi kategori di sebabkan karena pergantian media yang akan di gunakan tidak akan sanggup memuat bibit baru yang akan di pindahkan karena masih adanya tanaman yang lama yang belum di panen. Sedangkan indikator tidak terjadi pergantian bibit tanaman yaitu 34 skor dangan persentase $56.67 \%$ kategori tidak mengerti. Tingginya

$\begin{array}{llll}\text { STM } & \text { TM } & \text { RG } & \text { MG }\end{array}$

skor tersebut karena jika tidak ada pergantian bibit tanaman maka otomatis akan terhenti budidaya tanaman secara hidroponik.

Untuk gambaran lebih jelas mengenai persepsi masyarakat terhadap tanaman hidroponik dengan sub variabel pergantian bibit dapat dilihat pada gambar 10 dengan interpretasi nilai.

$\begin{array}{rrrrr} & & & & \\ 0 & 90 & & 180 & \\ & \text { Gambar } & 10 . & \text { Skala } & \text { Persepsi }\end{array}$

Masyarakat Terhadap Tanaman Hidroponik Dengan Sub Variabel Pergantian Bibit

$$
\begin{array}{ll}
\text { Keterangan } & : S M=\text { Sangat Mengerti } \\
& \text { MG }=\text { Mengerti } \\
\text { RG }=\text { Ragu-ragu } \\
\text { TM }=\text { Tidak Mengerti } \\
\text { STM } \quad=\text { Sangat Tidak }
\end{array}
$$

Mengerti

Dari Gambar 10. Dapat di jelaskan bahwa total skor 285, untuk persepsi masyarakat terhadap tanaman hidroponik skor (180 - 360) dengan kategori ragu-ragu. Hal ini menurut jawaban responden masyarakat bahwa sebagian mengetahui pergantian bibit, dan sebagiannya lagi masih belum mengerti pergantian bibit tanaman hidroponik.

\section{Persepsi Dari Karakteristik Faktor Pribadi.}

Persepsi masyarakat terhadap tanaman hidroponik dari segi karakteristik faktor pribadi, dapat di jelaskan sebagai berikut :

\section{Stimulus}

Untuk melihat persepsi masyarakat di Desa Lotta Kecamatan Pineleng. Mengenai persepsi masyarakat terhadap tanaman hidroponik dengan sub variabel stimulus dapat di lihat pada tabel 15 (Tabel dilampirkan).

Dari tabel 15 dapat dijelaskan bahwa total skor yang diperoleh yaitu 251 skor

$270 \quad 360 \quad 450$

dengan kategori setuju. Hal ini menyatakan bahwa tanaman hidroponik memiliki stimulus yang baik karena bisa membuat masyarakat begitu antusias untuk berhidroponik. Diantara kedua indikator di peroleh nilai skor yang sangat tinggi yaitu 76 skor dengan persentase $63.34 \%$ pada indikator respon di kategori setuju. Hal ini di sebabkan karena tanaman hidroponik memiliki perbedaan cara penanaman dibandingkan dengan cara yang konvensional yang menggunakan

tanah sebagai media untuk pertumbuhan tanaman sehingga memiliki respon yang baik dari masyarakat untuk berhidroponik. Indikator kesadaran yaitu 64 skor dengan persentase $53.33 \%$ pada kategori setuju. Tinggi kategori di sebabkan karena pemanfaatan tanaman hidroponik ini begitu sehat karena tidak ada penggunaan pestisida dan bahan kimia yang berbahaya lainnya, sehingga menimbulkan kesadaran bagi masyarakat untuk berhidroponik dan juga agar bisa membantu kebutuhan pangan yang ad di Desa Lotta.

Untuk gambaran lebih jelas mengenai persepsi masyarakat terhadap tanaman hidroponik dengan sub variabel stimulus dapat dilihat pada gambar 11 dengan interpretasi nilai.
STS TS

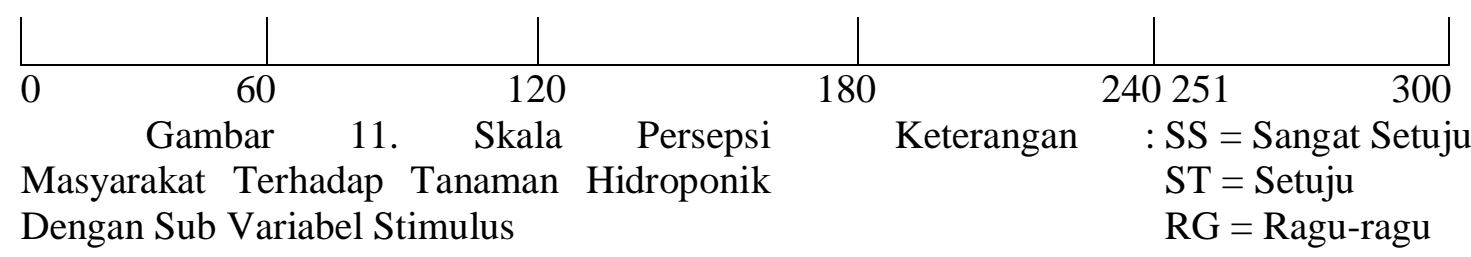


TS = Tidak Setuju

STS $=$ Sangat Tidak Setuju

Dari Gambar 11. Dapat di jelaskan bahwa total skor 251, untuk persepsi masyarakat terhadap tanaman hidroponik skor (240 - 300) dengan kategori setuju. Hal ini menurut jawaban responden bahwa dengan bercocok tanam dengan cara hidroponik sangatlah tidak sulit, di bandingkan dengan cara yang konvensional.

\section{Faktor Pribadi}

Untuk melihat persepsi masyarakat di Desa Lotta Kecamatan Pineleng. Mengenai persepsi masyarakat terhadap tanaman hidroponik dengan sub variabel factor pribadi dapat di lihat pada tabel 16 (Tabel dilampirkan).

Dari tabel 16 dapat dijelaskan bahwa total skor yang diperoleh yaitu 251 skor dengan kategori setuju .Hal ini menyatakan bahwa dengan kelebihan-kelebihan tanaman hidroponik responden bisa kemauan dan

STS TS

RG
ST SS

kemampuan untuk menanam tanaman hidroponik . Diantara kedua indikator di peroleh nilai skor yang sangat tinggi yaitu 56 skor dengan persentase $46.67 \%$ pada indikator kemauan di kategori setuju. Hal ini di sebabkan karena tanaman hidroponik memiliki banyak keuntungan sehingga timbulnya kemauan dari masyarakat untuk berhidroponik. Sedangkan indikator motivasi yaitu 75 skor dengan persentase $50 \%$ pada kategori sangat setuju. Tinggi kategori di sebabkan karena selain tanaman hidroponik bisa ditanam di daerah perkotaan tanaman hidroponik ini juga memiliki keuntungan yaitu tanaman ini bisa di tanam di segala musim, sehingga timbulnya motivasi dari responden untuk berhidroponik.

Untuk gambaran lebih jelas mengenai persepsi masyarakat terhadap tanaman hidroponik dengan sub variabel faktor pribadi dapat dilihat pada gambar 12 dengan interpretasi nilai.

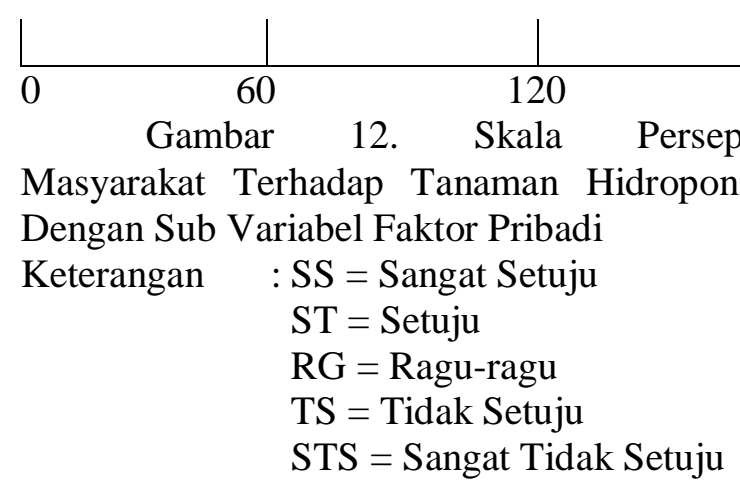

Dari Gambar 12. Dapat di jelaskan bahwa total skor 251, untuk persepsi masyarakat terhadap tanaman hidroponik skor (240 - 300) dengan kategori setuju. Hal ini menurut jawaban responden bahwa dengan setiap keuntungan yang ada membuat tanaman hidroponik lebih unggul dari tanaman yang di tanam secara konvensional, sehingga bisa merubah faktor pribadi responden dari yang tidak suka menanam hidroponik menjadi suka karena termotivasi akan keuntungan dari tanaman hidroponik.

\section{Faktor Pengaruh Kelompok}

Untuk melihat persepsi masyarakat di Desa Lotta Kecamatan Pineleng. Mengenai

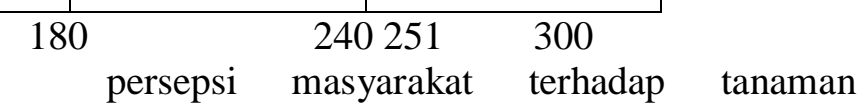
hidroponik dengan sub variabel faktor pengaruh kelompok dapat di lihat pada tabel 17 (Tabel dilampirkan).

Dari tabel 17 dapat dijelaskan bahwa total skor yang diperoleh yaitu 273 skor dengan kategori sangat setuju. Hal ini menyatakan bahwa dengan pengaruh kelompok menyebabkan banyaknya ke ikut sertaan masrayakat untuk berhidroponik lebih besar, karena pengaruh kelompok yaitu memanggil para masyarakat untuk ikut berhidroponik dengan mengsosialisasikan keuntungan tanaman hidroponik. Diantara kedua indikator di peroleh nilai skor yang sangat tinggi yaitu 105 skor dengan persentase $70 \%$ pada indikator ikut serta di kategori sangat setuju. Hal ini di sebabkan karena ke ikut sertaan masyarakat dalam kelompok untuk berhidroponik membuat kedekatan satu dengan lainnya lebih terjaga. Sedangkan indikator bersama-sama yaitu 75 skor dengan persentase $50 \%$ pada kategori sangat setuju. Tinggi kategori di sebabkan karena dengan 
bersama-sama membudidayakan tanaman hidroponik bisa menghasilkan tanaman hidroponik dengan kualitas yang maksimal untuk dikonsumsi atau pun untuk di jual dan tentunya memiliki harga jual yang tinggi.
Untuk gambaran lebih jelas mengenai persepsi masyarakat terhadap tanaman hidroponik dengan sub variabel faktor pengaruh kelomok dapat dilihat pada gambar 13 dengan interpretasi nilai.

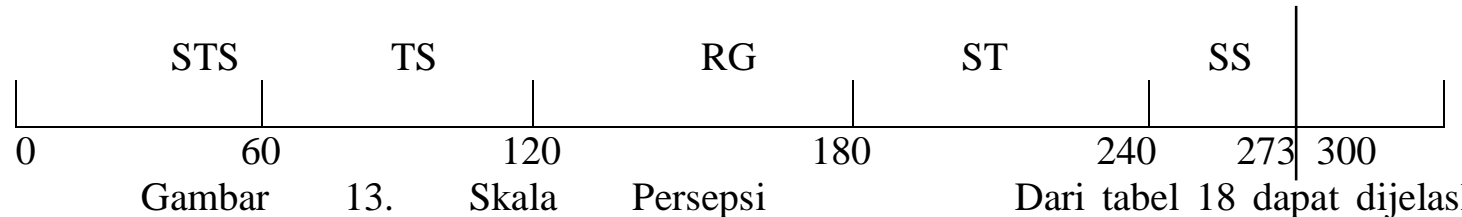

Masyarakat Terhadap Tanaman Hidroponik Dengan Sub Variabel Faktor Pengaruh Kelompok

Keterangan

$$
\begin{aligned}
& \text { : SS = Sangat Setuju } \\
& \text { ST = Setuju } \\
& \text { RG = Ragu-ragu } \\
& \text { TS = Tidak Setuju } \\
& \text { STS = Sangat Tidak Setuju }
\end{aligned}
$$

Dari Gambar 13. Dapat di jelaskan bahwa total skor 273, untuk persepsi masyarakat terhadap tanaman hidroponik skor (240 - 300) dengan kategori sangat setuju. Hal ini menurut jawaban responden bahwa dengan pengaruh kelompok membuat ke ikut sertaan masyarakat lebih bertambah dan juga membuat kerja sama kelompok lebih maksimal untuk mengoah tanaman hidroponik.

\section{Faktor Kultural}

Untuk melihat persepsi masyarakat di Desa Lotta Kecamatan Pineleng. Mengenai persepsi masyarakat terhadap tanaman hidroponik dengan sub variabel faktor kultural dapat di lihat pada tabel 18 (Tabel dilampirkan).

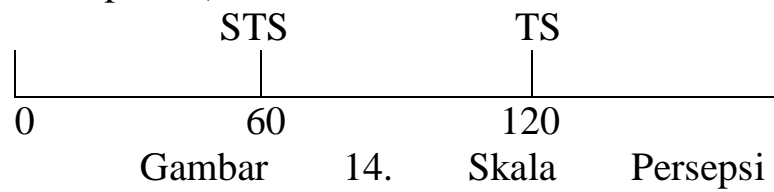

Masyarakat Terhadap Tanaman Hidroponik Dengan Sub Variabel Faktor Kultural

$$
\begin{array}{ll}
\text { Keterangan } & \text { : SS = Sangat Setuju } \\
& \text { ST = Setuju } \\
& \text { RG = Ragu-ragu } \\
& \text { TS = Tidak Setuju } \\
& \text { STS = Sangat Tidak Setuju }
\end{array}
$$

Dari Gambar 14. Dapat di jelaskan bahwa total skor 260, untuk persepsi masyarakat terhadap tanaman hidroponik skor (240 - 300) dengan kategori setuju. Hal ini

\section{total skor yang diperoleh yaitu 260 skor} dengan kategori setuju. Hal ini menyatakan bahwa responden lebih menyukai bahwa ada cara bercocok tanam secara hidroponik di Desa Lotta. Diantara kedua indikator di peroleh nilai skor yang sangat tinggi yaitu 100 skor dengan persentase $66.67 \%$ pada indikator persetujuan masyarakat di kategori sangat setuju. Hal ini di sebabkan karena masyarakat setuju dengan adanya tanaman hidroponik di Desa Lotta, masyarakat menginginkan agar pemanfaatan tanaman hidroponik lebih di kembangakan lagi. Sedangkan indikator adaptasi lingkungan yaitu 72 skor dengan persentase $60 \%$ pada kategori setuju. Tinggi kategori di sebabkan karena tanaman hidroponik tidak mencemari lingkungan, dan masyarakat bisa menerima tanaman hidroponik bisa masuk di Desa Lotta

Untuk gambaran lebih jelas mengenai persepsi masyarakat terhadap tanaman hidroponik dengan sub variabel faktor kultural dapat dilihat pada gambar 14 dengan interpretasi nilai.

$\begin{array}{ccc}\text { RG } & \text { ST } & \text { SS } \\ \mid & 240 & 260\end{array}$

menurut jawaban responden bahwa responden menerima adanya tanaman hidroponik dan dengan adanya tanaman hidroponik memberikan efek yang baik bagi masyarakat karena memiliki hasil yang menguntungkan.

\section{Total Persepsi Secara Keseluruhan}

Penilaian pengetahuan masyarakat di Desa Lotta Kecamatan Pineleng terhadap persepsi secara keseluruhan daapat di lihat pada tabel 19. 
Tabel 19. Hasil Rekapitulasi Penilaian Pengetahuan Masyarakat Terhadap Persepsi Di Desa Lotta Kecamatan Pineleng.

\begin{tabular}{|c|c|c|c|c|}
\hline No & Variabel & Sub Variabel & Nilai & Keterangan \\
\hline \multirow{11}{*}{1.} & \multirow{11}{*}{ Pengetahuan } & Budidaya Tanaman Hidroponik & 282 & Mengerti \\
\hline & & Bibit & 322 & Mengerti \\
\hline & & Penanaman & 375 & Mengerti \\
\hline & & Memindahkan Bibit Tanaman & 345 & Mengerti \\
\hline & & Merawat Tanaman & 261 & Ragu-ragu \\
\hline & & Panen & 339 & Mengerti \\
\hline & & Pembersihan Pipa & 283 & Ragu-ragu \\
\hline & & $\begin{array}{c}\text { Pengontrolan Pompa Air Untuk } \\
\text { Sirkulasi }\end{array}$ & 278 & Ragu-ragu \\
\hline & & Pemberian Nutrisi Tanaman & 285 & Ragu-ragu \\
\hline & & Pergantian Bibit & 270 & Ragu-ragu \\
\hline & & Jumlah & 3.040 & Mengerti \\
\hline No & Variabel & Sub Variabel & Nilai & Keterangan \\
\hline \multirow{6}{*}{2.} & \multirow{6}{*}{$\begin{array}{l}\text { Karakteristik Faktor } \\
\text { Pribadi }\end{array}$} & Stimulus & 251 & Setuju \\
\hline & & Faktor Pribadi & 251 & Setuju \\
\hline & & Faktor Pengaruh Kelompok & 273 & Sangat Setuju \\
\hline & & Faktor Kultural & 260 & Setuju \\
\hline & & Jumlah & 1.035 & Setuju \\
\hline & & Total & 4075 & Mengerti/Setuju \\
\hline
\end{tabular}

Berdasarkan tabel 20 dapat di lihat bahwa hasil penilaian responden terhadap persepsi secara keseluruhan adalah mengerti/setuju dengan total bobot 4075. Penilaian dari variabel pengetahuan dengan sub variabel meliputi budidaya tanaman hidroponik dengan indikator keuntungan, lebih baik, di berbagai musim dengan bobot 282 , bibit dengan indikator bibit di ambil dari luar, bibit di ambil dari toko, bibit di buat sendiri dengan bobot 322, Penanaman dengan indikator tebar benih secara teratur, mengamburkan benih, penyamaian dengan bobot 375, memindahkan bibit tanaman dengan indikator memerlukan wadah gelas, langsung menuju pipa untuk memindahkan bibit tanaman, dan menggunakan bsah untuk bibit tanaman dengan bobot 345 , merawat tanaman dengan indikator merawat tanaman setiap hari, merawat tanaman seminggu sekali, merawat tanaman sebulan sekali dengan bobot 261, panen dengan indikator penen di lakukan perorangan, panen di 
lakukan menyewa pekerja, pemanenan dengan alat seadanya dengan bobot 339 , pembersihan pipa dengan indikator dilakukan setelah panen, di lakukan dua minggu sekali, di lakukan satu bulan sekali dengan bobot 283, pengontrolan pompa air sirkulasi dengan indicator mengontrol secara rutin, mengontrol kadangkadang, tidak perlu di kontrol dengan bobot 278, pemberian nutrisi tanaman dengan indikator pemberian nutrisi dua hari, pemberian

nutrisi dua minggu, pemberian nutrisi satu bulan sekali dengan bobot 285. Pergantian bibit dengan indikator bibit di ganti setelah panen, pergantian bibit sebelum panen, tidak ada pergantian bibit tanaman dengan bobot 270 . Dengan jumlah pada variabel pengetahuan yaitu 3.040 yang berkategorikan mengerti. Penilaian pada variabel kerakteristik fakor pribadi dengan sub fariabel meliputi Stimulus dengan indikator respon, kesadaran dengan bobot 251, faktor $\mathrm{S} 5=5 \times 30=150 \times 38=5700$

$\mathrm{S} 4=4 \times 30=120 \times 38=4560$

$\mathrm{S} 3=3 \times 30=30 \times 38=3420$

$\mathrm{S} 2=2 \times 30=60 \times 38=2280$

$\mathrm{S} 1=1 \times 30=30 \times 38=1140$ pribadi dengan indikator kemauan, motivasi dengan bobot 251, pengaruh faktor kelompok dengan indikator ikut serta, bersama-sama dengan bobot 273, faktor kultural dengan indikator persutujuan masyarakat, adaptasi lingkungan dengan bobot 260. Dengan jumlah pada variabel karakteristik faktor pribadi yaitu 1.035 yang berkategorikan setuju.

Cara perhitungan skor keseluruhan untuk mengetahui tingkat persepsi masyarakat terhadap tanaman hidroponik :

Jumlah Skor Seluruh Kriterium = Capaian Jumlah Skor x Jumlah Responden x Jumlah Pertanyaan

Jumlah skor ideal untuk keseluruhan pertanyaan $=5700$ (Sangat Mengerti/Sangat Setuju), sedangkan jumlah skor terendah adalah 1140 (Sangat Tidak Mengerti/Sangat Tidak Setuju) berdasarkan data yang telah di olah, maka diperoleh total skor 4075. Untuk mendapatkan gambaran yang jelas mengenai

persepsi secara keseluruhan dapat di lihat pada gambar 15 dengan interpretasi nilai.

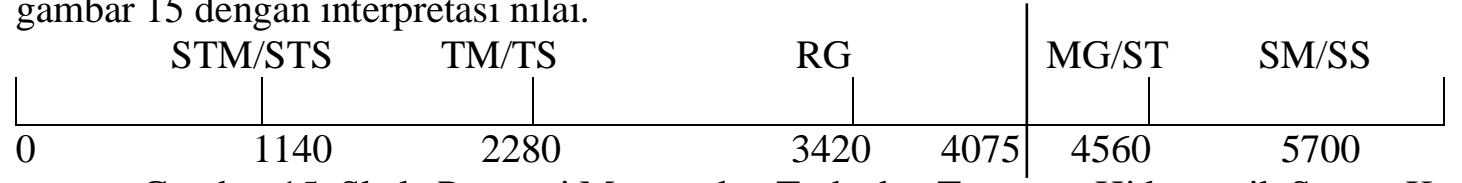

Gambar 15. Skala Persepsi Masyarakat Terhadap Tanaman Hidroponik Secara Keseluruhan Keterangan :SM/SS = Sangat Mengerti/Sangat Setuju

$\mathrm{MG} / \mathrm{ST}=$ Mengerti/Setuju

$\begin{array}{ll}\text { RG } & =\text { Ragu-ragu } \\ \text { TM/TS } & =\text { Tidak Mengerti/Tidak Setuju } \\ \text { STM/STS } & =\text { Sangat Tidak Mengerti/Sangat Tidak Setuju }\end{array}$

Pada gambar 15, dapat di lihat jumlah skor sebanyak 4075 untuk persepsi masyarakat secara keseluruhan skor $(3420$ - 5700) termasuk kategori mengerti/setuju. Hal ini menyatakan bahwa responden mengetahui pengetahuan dan mengerti cara penanaman tentang tanaman hidroponik serta karakteristik dari responden yang menyatakan bahwa tanaman hidroponik sangat menguntungkan sehingga masyarakat sangat menyukai bercocok tanam secara hidroponik dan memberikan efek positif di Desa Lotta karna melihat persepsi responden yang berkategorikan mengerti/setuju.

Analisis yang digunakan merupakan analisis deskriptif yang dianalisis dengan menggunakan skala likert menurut, Riduwan (2008) dalam buku rumus dan data analisis statistika sebagai berikut :

Persepsi Masyarakat $=\frac{\text { JumlahSkorHasilPengumpulanData }}{\text { JumlahSkorIdeal }(\text { Tertinggi) }} \times 100 \%$ 
Persepsi Masayrakat $=\frac{4075}{5700} \times 100 \%=71 \%$

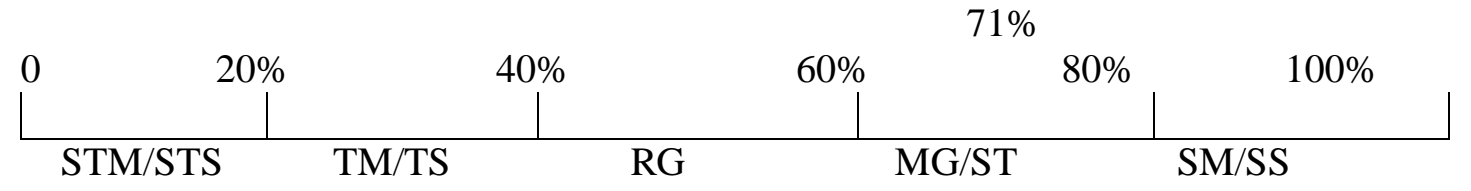

Gambar 16. Skala Persepsi Masyarakat Terhadap Tanaman Hidroponik Secara Keseluruhan Persentase.

Berdasarkan hasil analisis menggunakan skala likert, maka dapat diketahui bahwa angka indeks persepsi masyarakat terhadap tanaman hidroponik di Desa Lotta Kecamatan Pineleng adalah sebesar $71 \%$ dan tergolong dalam kategori mengerti/setuju.

Hasil wawancara pada responden di Desa Lotta menunjukan faktor yang menyebabkan persepsi masyarakat di kategori baik kepada tanaman hidroponik. Responden mengerti tentang tanaman hidroponik dan bertanggapan persepsi lewat pengetahuaan tanaman hidroponik bahwa responden mengerti penanaman hidroponik serta keuntungan dan kelebihan dari pemanfaatan tanaman tersebut karena keuntungan dan kelebihannya yaitu harga jual yang lebih tinggi di bandingkan tanaman yang di tanam secara konvensional, tidak menggunakan pestisida, masa pertumbuhan lebih cepat, hasil lebih maksimal, bisa di tanam di musim apa pun, bisa ditanam di daerah perkotaan, cara pengurusan tanaman yang mudah hanya menjaga kestabilitas air serta penambahan nutrisi secara teratur. Dan menurut responden diera yang sudah seperti sekarang, harus di kembangkan tanaman hidroponik agar masyarakat juga bisa ikut menanam tanaman hidroponik dan agar kebutuhan pangan untuk masyarakat bisa lebih bertambah.

\section{KESIMPULAN DAN SARAN}

\section{Kesimpulan}

Hasil penelitian persepsi masyarakat terhadap tanaman hidroponik di Desa Lotta Kecamatan Pineleng berkategorikan mengerti/setuju bahwa karena melihat dari hasil yang di dapat, bahwa responden menggerti akan hidroponik serta mengerti cara penanaman tanaman hidroponik dan menyukai akan tanaman hidroponik.

\section{Saran}

Tanaman hidroponik bisa lebih di kembangkan agar di kenal, dengan cara mengadakan sosialisasi atau penyuluhan tentang tanaman hidroponik agar supaya lebih banyak lagi msyarakat yang mengembangkan cara becocok tanaman dengan cara hidroponik, karena memiliki banyak keuntungan dan kelebihan dari tanaman yang di tanam secara konvensional.

\section{DAFTAR PUSTAKA}

Arifin, Z. (2008). Beberapa Unsur Mineral Esensial Mikro Dalam Sistem Biologi Dan Metode Analisisnya. Balai Besar Penelitian Bogor. Jurnal

Andhika, P. (2009). Analisis Kelayakan Dan Optimasi Usaha Budidaya Bayam Merah Dan Kangkung Hidroponik Dengan Sistem (NFT) Di PT.Joy Farm Depok. Institut Pertanian Bogor. Jurnal

Hendra, A.H. \& Andoko, A. (2014). Bertanam Sayuran Hidroponik Ala Pak Tani The Farmer Hydrofarm. PT Agromedia Pustaka

Ken Suratiyah. (2015). Ilmu Usaha Tani. Penebar Swadaya. Jakarta

Notohadiprawiro, T. (2006). Tanah Dan Lingkungan Ilmu Tanah Universitas Gadjah Mada. Jurnal

Nitisusastro, M.H. (2013). Perilaku Konsumen Dalam Perspektif Kewirausahaan. ALVABETA, CV.

Novianti, S. (2011). Analisis Resiko Produksi Bayam Dan Kangkung Hidroponik Pada Parung Farm Kabupaten Bogor Provinsi Jawa Barat. Institut Pertanian Bogor Universitas. Jurnal 
Perwatasari, B. (2012). Pengaruh Media Tanam Dan Nutrisi Terhadap Pertumbuhan Dan Hasil Tanaman Pakchoi. Fakultas Pertanian Universitas Trunojoyo Madura. Jurnal

Rachman, M. (2013). Persepsi Masyarakat Terhadap Keberadaan Peternak Babi Kampung Katimbang Kelurahan Paccerakkang Kecamatan Biringkanaya, Makassar. Universitas Hasanuddin Makassar. Skripsi

Riduwan, (2008). Rumus Dan Data Dalam Analisis Statistik. Penerbit Alfabeta. Bandung

Sibarani, S. M. (2005). Analisis Sistem Irigasi Hidroponik (NFT) pada Budidaya Tananman Selada. Fakultas Pertanian Universitas Sumatera Utara. Jurnal.
Sugiyono. 2012. Metode Penelitian Bisnis (Pendekatan Kuantitatif, Kualitatif, Dan R\&D). Bandung : Alfabeta.

Setiawati, A. (2010). Identifikasi FaktorFaktor Yang Mempengaruhi Persepsi Masyarakat Dalam Pemilihan Partai Politik Di Daerah Rawan Konflik Melalui Model Persamaan Struktural (MPS). Institut Pertanian Bogor.Skripsi

Yusri, A. (1999). Faktor-Faktor Yang Mempengaruhi Persepsi Petani Terhadap Kredibilitas Penyuluhan Pertanian. Institut Pertanian Bogor Universitas. Skripsi

Yustika, A.E. (2015). Konsep Ekonomi Kelembagaan. Empat Dua. Malang, Jatim 